\title{
COMPACTION AND POROSITY BASED PORE PRESSURE PREDICTION IN THE "CAPPE FIELD", COASTAL SWAMP DEPOBELT, NIGER DELTA, NIGERIA
}

AYONMA W. MODE, OKWUDIRI A. ANYIAM AND EVLYN N. NGALA

(Received 16 May 2013; Revision Accepted 21 August 2013)

\begin{abstract}
Three wells of the "Cappe" Field in the offshore part of the Coastal Swamp depobelt I, Niger Delta, were evaluated primarily to determine the impact of compaction on reservoir quality and to determine possible overpressured zones in the Benin and Agbada formations. Sandstone porosity-depth plots of the three wells show a linear trend of gradual porosity reduction with depth for the top of the wells 1,2 and $3\left(r^{2}=0.26,0.42\right.$ and 0.73 at $4500-$ 5900ft, 3940-5000ft and 2500-5350ft respectively). Two variations from this simple trend were observed. 1: Intervals of insignificant porosity reduction (well $1 ; 6500-7950 \mathrm{ft}, \mathrm{r}^{2}=0.00003$ and well $2 ; 5760-7911 \mathrm{ft}, \mathrm{r}^{2}=0.008$ ), due to hydrocarbon entrapment. 2: A reversal in the trend (well 3; 5450-9658ft, $r=-0.89$ ) indicated by an increase in porosity as a result of overpressure. A number of factors such as compaction, fluid content and pore pressure affect the porosity-depth trends of the Agbada Formation. A decrease in porosity with depth generally holds true for shales (well 1: $r^{2}=0.74$ and well 2: $\left.r^{2}=0.81\right)$ except for an increase in porosity $\left(r^{2}=-0.596\right)$ observed in well 3 . Compaction factor is significant in sandstone porosity reduction in the Benin Formation (well 1: $58.3 \%$ and well 2: $68.9 \%$ ) than in the Agbada Formation (well 1: $25.64 \%$ and well 2: $25.29 \%$ ). Sandstone porosities predicted at the base of the wells are generally low (well 1: $5.86 \%$, well 2: $7.52 \%$ ), implying uneconomical reservoirs.
\end{abstract}

KEY WORDS: Pore Pressure, Overpressure, Porosity, Compaction

\section{INTRODUCTION}

Porosity loss in sandstones is of concern, because it affects the nature of oil and gas reservoirs. Shale porosity - depth plots are also important because although fluid pressures are reflected in shale, pressures cannot be measured directly but can be estimated from shale porosity-depth trends. The compaction coefficient "C" governs the compaction of sediments and it is a function of the depositional environment (Luo and Vassuer, 1992). The compaction coefficient changes from field to field and even from one sediment section to another in the same field. But for a given section, it does not change in a normal compaction zone during burial. Therefore, the coefficient actually represents the characteristics of sediment fabrics. The larger the compaction coefficient, the greater the decrease in porosity with burial (Luo and Vassuer, 1992). According to Weber and Daukoru (1988), compaction in the Niger Delta varies from one depobelt to another. Each depobelt has its own porosity-depth relationships; the deepest buried depobelt (Central Swamp) has the highest porosity at greater depth, whereas the younger depobelt (Coastal swamp) has lower porosities at shallower depth (Weber and Daukoru, 1988). Generally, porosity-depth trends are studied because of the need to understand:

1: the impact of compaction on the evolution of possible reservoirs, 2: the nature of porosity-depth trends, to aid in reservoir quality prediction in areas yet to be drilled and 3: the variations in pore pressure, to avoid problems related to overpressures.

Though the Niger Delta Delta Basin is regarded as a "mature hydrocarbon province" enhanced ability to predict reservoir quality with depth and possible overpressured zones will minimize uncertainties and risks associated with drilling especially the deeper targets. The present study was carried out using wireline logs of three wells in the "Cappe Field", Coastal Swamp Depobelt, Niger Delta (Fig.1). The objectives are to evaluate the nature of porosity-depth trends, determine the impact of compaction on the reservoirs quality and estimate pore pressure from wireline data.

Ayonma W. Mode, Department of Geology, University of Nigeria, Nsukka, Nigeria

Okwudiri A. Anyiam, Department of Geology, University of Nigeria, Nsukka, Nigeria

Evlyn N. Ngala, Department of Geology, University of Nigeria, Nsukka, Nigeria 


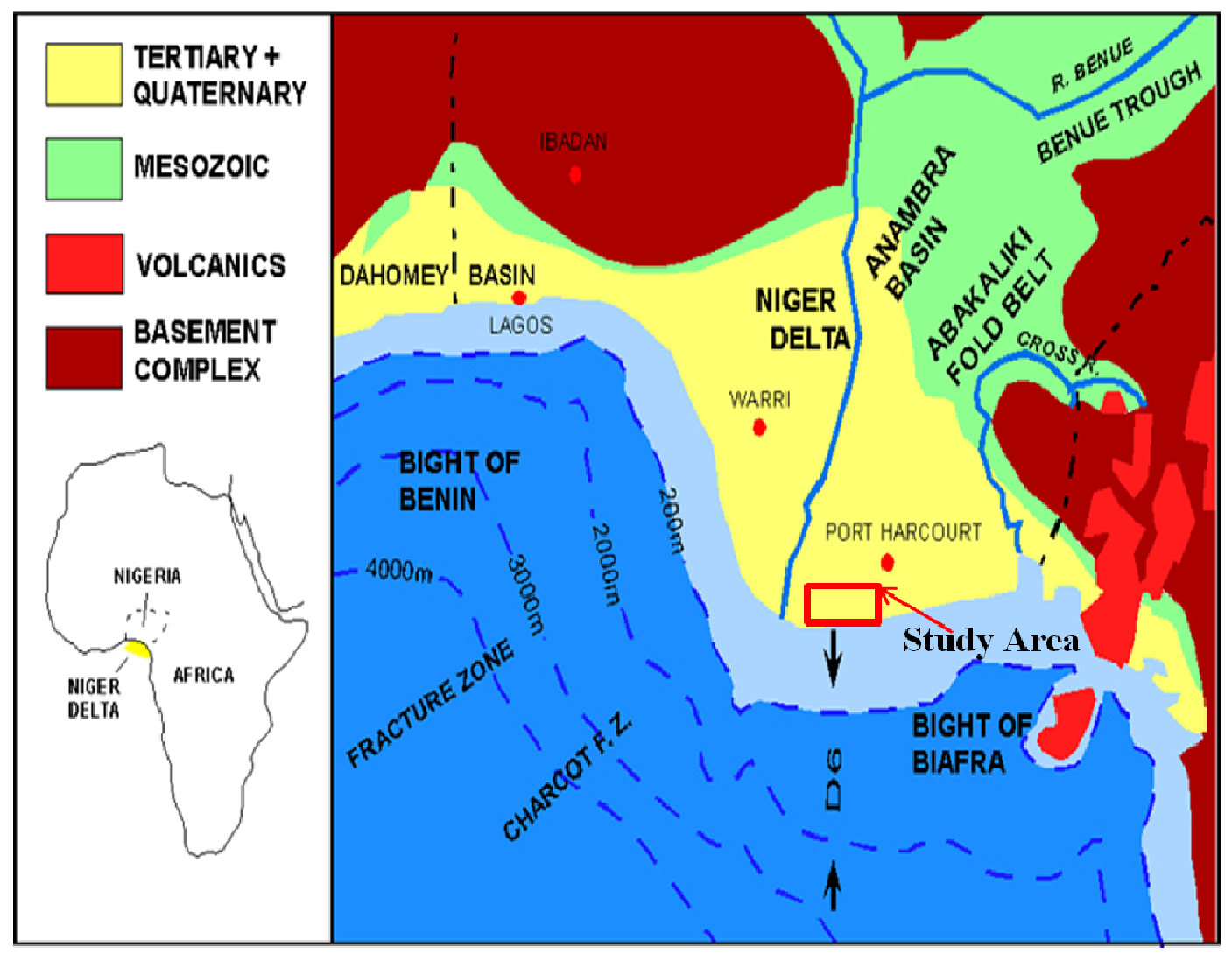

Fig.1: Map of Niger Delta Nigeria showing the study area (Modified from Tuttle et al (1999)

\section{Geologic Setting and Stratigraphy of the Niger Delta}

The Tertiary Niger Delta is situated in the Gulf of Guinea in West Africa (Fig.1). It is located at the intersection of the Benue Trough and the South Atlantic Ocean where a triple junction developed the separation of South American and African plates during the lower Cretaceous. The delta covers a total surface area of about 75,000 square kilometers (Evamy et al, 1978, Reijers et al, 1997) and is located between latitudes $3^{\circ}$ and $6^{\circ} \mathrm{N}$ and longitudes $5^{0}$ and $8^{0} \mathrm{E}$ (Reijers et al, 1997). The basin fill consist of rapidly varying alternations of clastic lithologies, occurring in stacked sections of regressive offlap cycles (Doust, 1989). The sedimentary fill reaches a maximum of $9,000-12000 \mathrm{~m}$ (30-40,000ft) in the central part of the Niger Delta and is delineated into three subsurface lithostratigraphic units; Akata, Agbada and Benin formations (Table 1, Fig.2). The formations are strongly diachronous ranging from Paleocene to Recent in age (Short and Stauble, 1967; Merki, 1970). The Akata Formation which is the basal unit; consists predominantly of prodelta marine shales. Sandstones associated with this unit are generally lowstand turbidity fans deposited in deeper marine settings.

The Agbada Formation overlies the Akata Formation. It comprises mainly of sands in the upper part and alternation of sands and shales in equal proportion in the lower part. This unit is the delta front facies and was deposited in a paralic environment. The Benin Formation, comprising of continental sands and gravels, represents the delta top facies.

\section{Materials and Methods}

The data set used in this study comprises of wireline logs, which include the following: Gamma-ray, Sonic, Spontaneous Potential (SP), Caliper, Neutron, Density, and Resistivity (LLD, LLS and MSFL) logs. Gamma ray log signatures were used to delineate sand and shale intervals and to define the boundaries of the various formations (Fig.2). Petrophysical properties (porosity, 

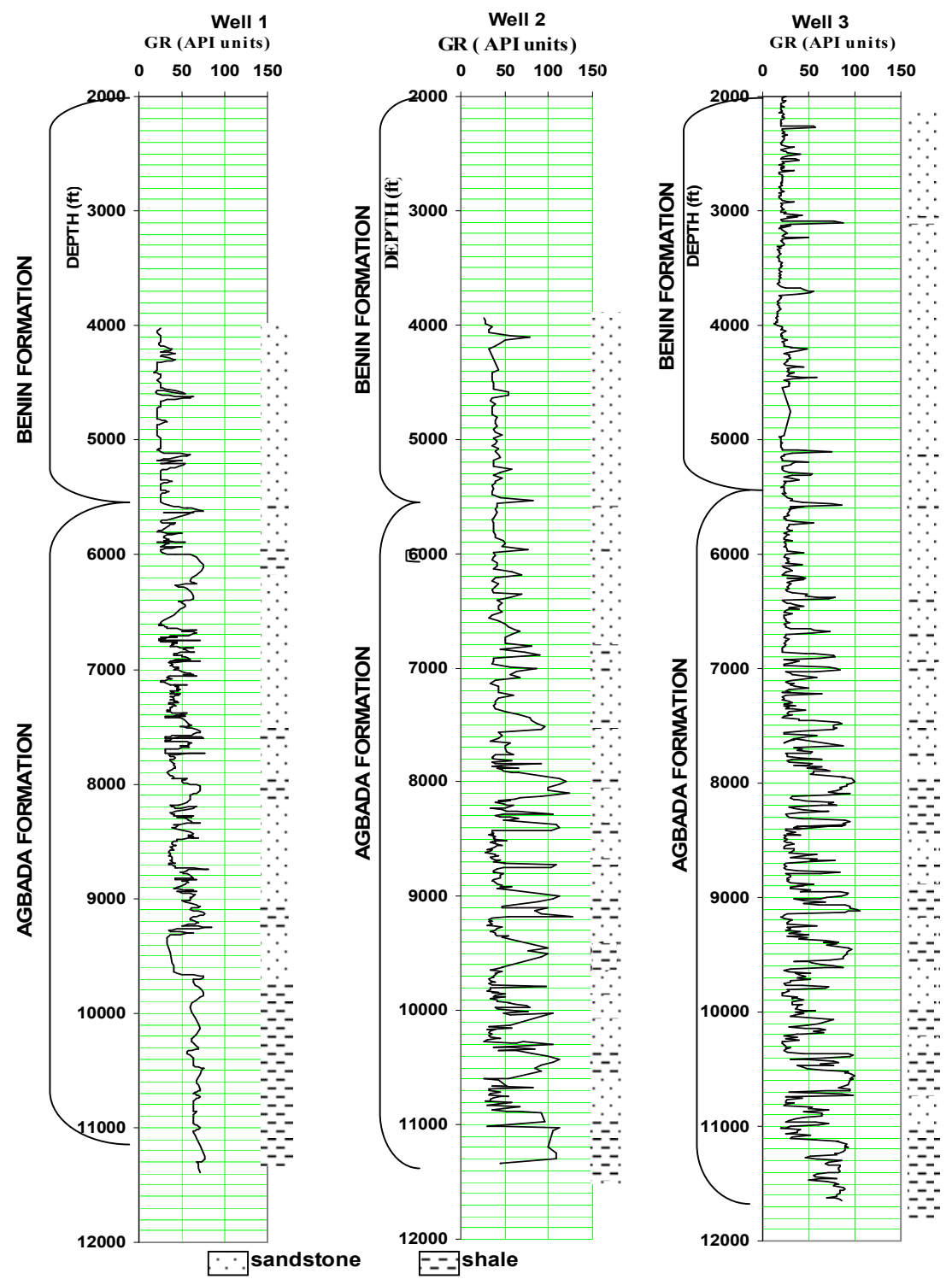

Fig.2: Lithologic succession in the three wells studied.

permeability, water and hydrocarbon saturation) which aid in identification of reservoir fluids were computed and reservoir units delineated (Fig. 3). Porosity values for shales were computed from the sonic logs. Porosity was plotted against depth for both sand and shale intervals. Water saturation and porosity against depth; was also plotted, to aid proper interpretation of results. The compaction coefficients and the degree of compaction were computed and shale pore pressures estimated using relevant equations. 


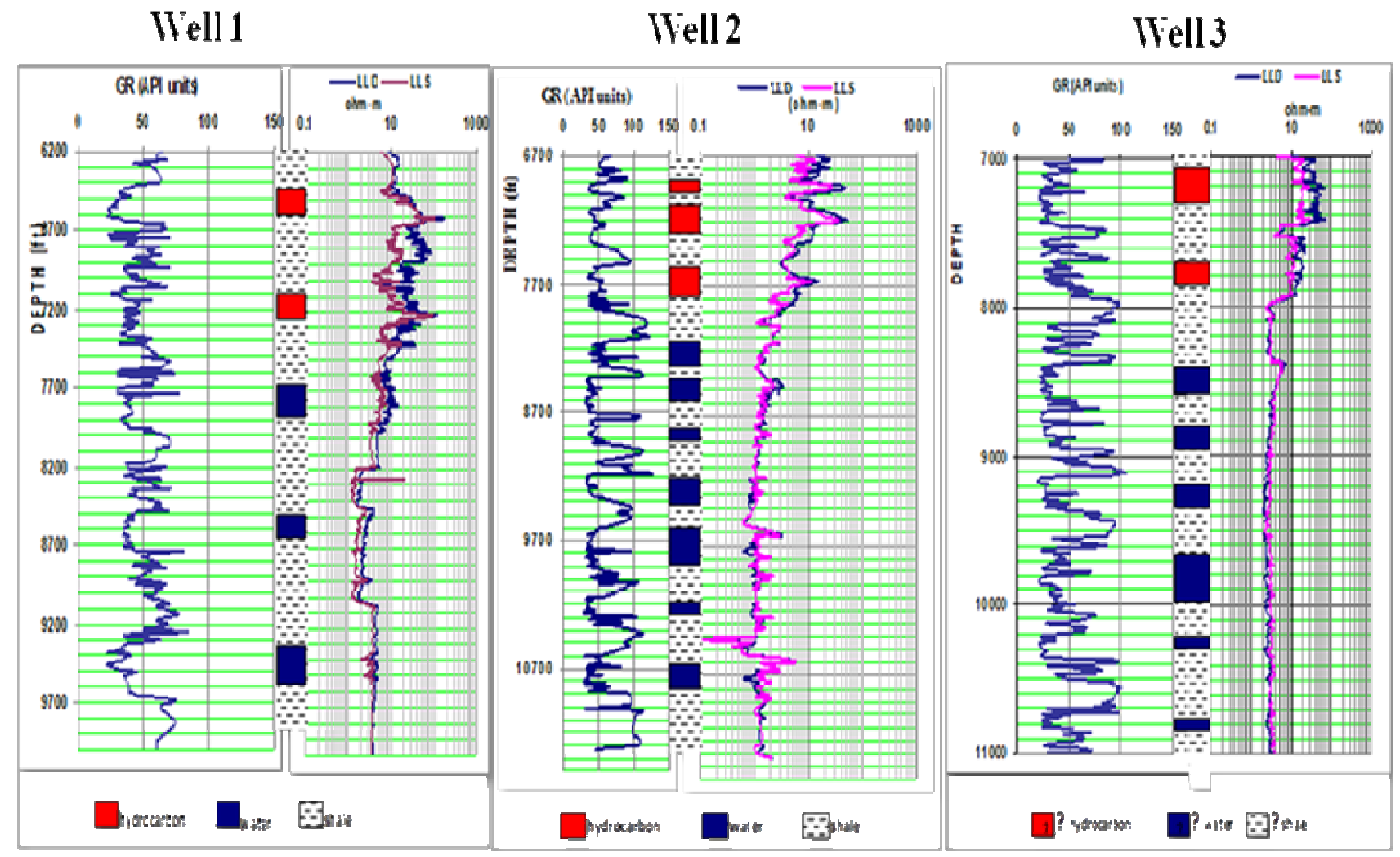

Fig.3: Reservoir delineations for well 1, well 2 and well 3.

\section{Degree of Compaction}

The degree of compaction was computed using Einsele (1992) equation. The ratio between the initial thickness (h1) and the secondary thickness (h2) is called the compaction ratio (CR). It directly indicates the reduction in thickness between a higher and lower interval in a sedimentary column. Since the initial thickness ( $\mathrm{h} 1$ ), is usually unknown, the compaction ratio is determined from the mean porosities $\mathrm{n} 1$ and $\mathrm{n} 2$ (Einsele, 1992). Porosity reduction was determined by using the maximum burial depth and porosity as reference depth and porosity.

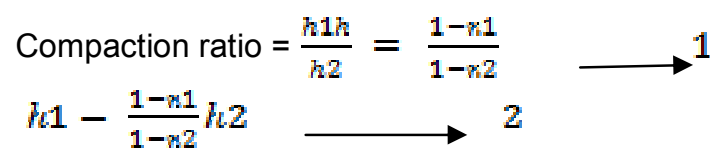

Where $h 1$ is the original thickness, $h 2$ is the present thickness, $n 1$ is the initial porosity (at zero depth), and $n 2$ is the present porosity.

\section{Porosity and Pressure Model}

Porosity based pore pressure prediction was built on the assumption that porosity is controlled solely by mechanical compaction (i.e. no chemical process is involved) (Swarbrick, 2002). Pore pressure evaluated in this study is that generated by mechanical compaction. It is a function of overburden stress and vertical effective stress (Yang et al., 2002).

The porosity based pore pressure model applied in this study was proposed by Athy (1930);

$$
\phi=\phi_{0} e^{-c z}
$$

Hurbbert and Rubey $\overrightarrow{(1959)}$ suggested that the form of porosity versus effective stress relation at geologic depths and pressure is exponential, modifying Athy (1930) equation to;

$$
\emptyset=\phi_{0} e^{-b(\sigma v)} \longrightarrow 4
$$

Where $\varnothing$ is the porosity of sediments, $\varnothing_{0}$ is the initial porosity, $c$ is the compaction coefficient, $b$ is compressibility factor, $z$ is the observing length, $\sigma \mathrm{V}$ is the vertical effective stress. Haney et al (2007) proposed that under hydrostatic conditions the effective stress increases with burial depth and is determined by the equation. 
$\sigma v=\rho_{f} g z \longrightarrow 5$

Where $\rho f$ is the density of fluid and $g$ is the acceleration due to gravity. Shale porosity is plotted against vertical effective stress in the hydrostatic zone to determine the initial porosity $(\varnothing 0)$ and the empirical constant $(\beta)$. These coefficients are then used to calculate fluid pressure throughout the wells.

Pore pressure prediction was done using the Terzaghi's stress relationship between total stress, effective stress and pore pressure (Swarbrick, 2002), in the simplified equation:

$\mathrm{P} 1=\sigma+\mathrm{Pp} \quad 6$

Where $P 1$ is the fotal vertical stress; $\sigma$ is the effective stress and Pp is the pore pressure. The total vertical stress (P1) is derived from the overburden by integrating the wireline bulk density log (Nagumo, 1965). A pore pressure model was derived by combining equations 4 and 6 ;

$$
\mathrm{Pp}=\mathrm{P} 1-\left[\frac{1}{\beta} \ln \left(\frac{0_{\mathrm{o}}}{\phi}\right)\right] \longrightarrow 7
$$

The porosity based pore pressure prediction model has been used by several authors; Hart et al (1995), Stump et al (1998), Flemings and Lupa (2004).

\section{RESULTS}

\section{Sandstone Porosity-Depth Plots}

The Benin Formation lies within the first $6000 \mathrm{ft}$ of all the wells studied. The Benin Formation was identified by a continuous sand succession with rare intervals of shale indicated by low gamma ray readings. The Agbada Formation (6000-12000ft) is recognized by alternating sand/shale successions, which get shalier with depth. This is indicated on the gamma ray log by a mixture of low (sands) and high (shales) gamma ray readings (Fig.2).

Sandstone porosity-depth plots show a linear trend of gradual porosity reduction with depth, at the top (Benin Formation) of all three wells $\left(r^{2}=0.26,0.42\right.$ and 0.73 at $4500-5900 \mathrm{ft}, 3940-5000 \mathrm{ft}$ and $2500-5350 \mathrm{ft}$ for wells 1,2 and 3 respectively).

Intervals of insignificant porosity reduction; $r^{2}=0.0003$ and 0.0087 were observed at depth ranges of $6500-7950 \mathrm{ft}$ (Fig. 4A) and 5760-7911ft (Fig.5A) for wells 1 and 2 respectively (Table.2) 

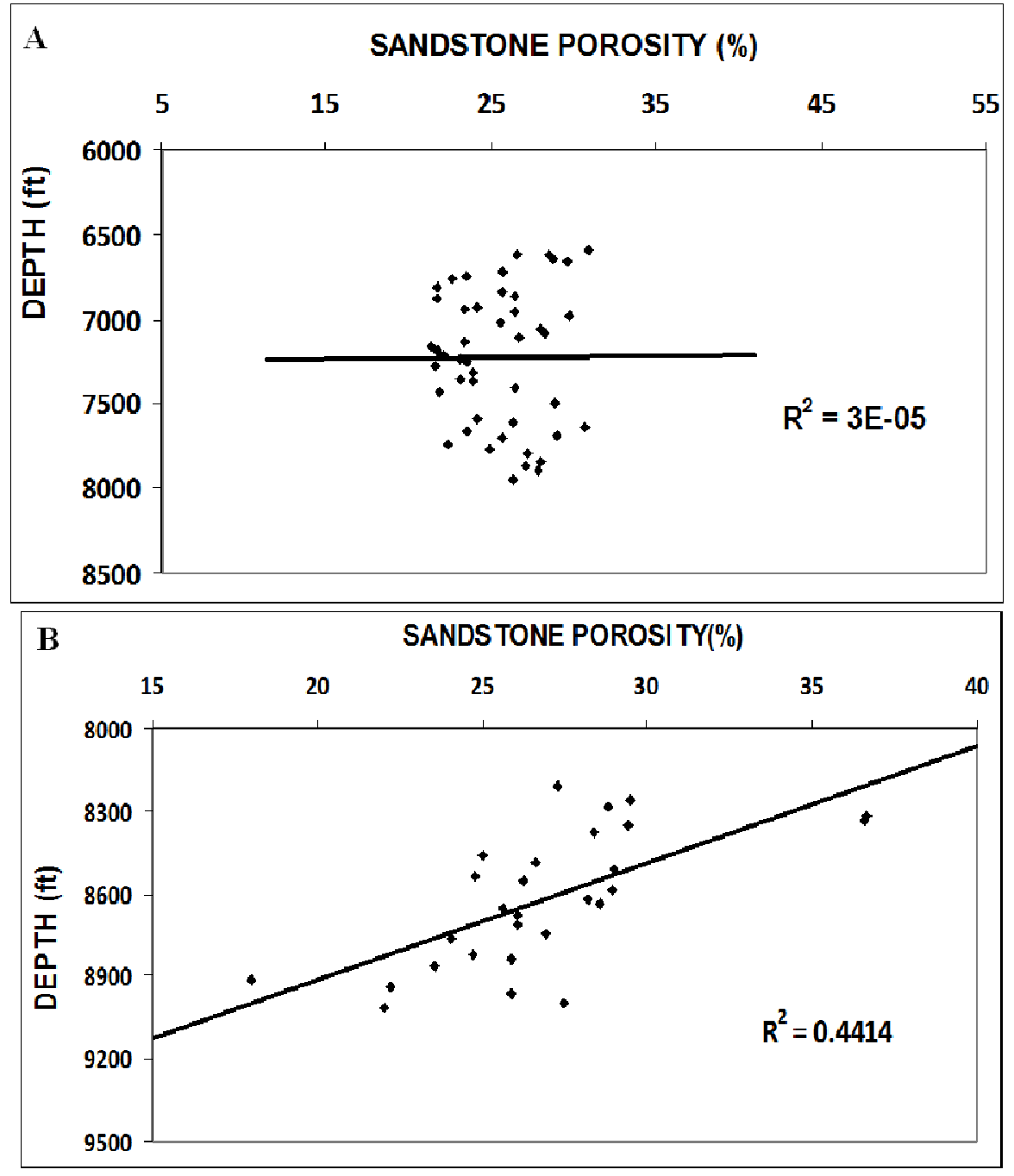

Fig.4: Sandstone Porosity-depth plot for (A) the intervals of 6500 - 7950ft (insignificant porosity reduction) and (B) intervals of $8211-9218 \mathrm{ft}$ (significant porosity reduction) in well 1. Porosity values range from $30.9-21.3 \%$

These intervals of insignificant porosity reduction coincide with the depths (6420-7380ft (well 1), 6900-7800ft (well 2)) at which hydrocarbon bearing zones occur (Fig. 3). The regression models; $Z=-149.99 \varnothing+10270$ and $Z=-174.57 \varnothing+$ 12366 , for the general plots of porosity against depth, predict porosity values in the range $25.14-15.47 \%$ and $37.8-$ $25.52 \%$ at depth ranges of $6500-7950 \mathrm{ft}$ and $5760-7911 \mathrm{ft}$, where insignificant porosity reduction were observed. 

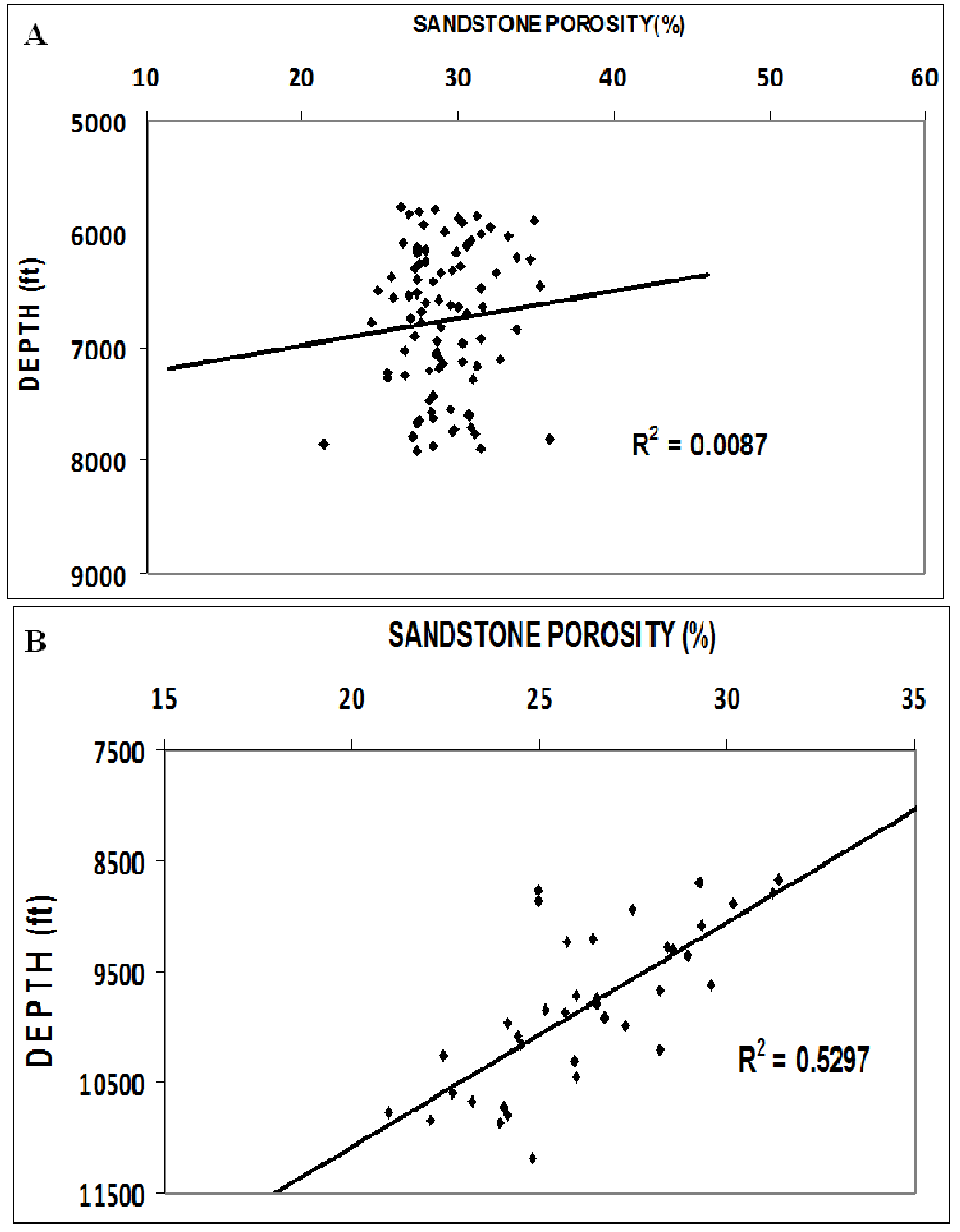

Fig.5: Sandstone Porosity-depth plot for the interval for (A) the intervals of $5760-7911 \mathrm{ft}$ (insignificant porosity reduction) and (B) intervals of 8669-11176 ft (significant porosity reduction) in well 2 . Porosity ranges from $35 \%$ $24.39 \%$

These porosity values predicted are lower than the observed values in well 1 , but correspond with the values observed in well 2.

The porosity-depth trends show an improved correlation of porosity reduction with depth $\left(r^{2}=0.44\right.$ and 0.53$)$ at the base of the wells (8211-9218 ft (well 1) and 8669-11176 ft (well 2) (Figs.4B and 5B). This reduction in porosity coincides with the water bearing zones which occur at depth ranges of 7850-9600 ft and 8154-10850 ft for wells 1 and 2 respectively (Fig.3).

Also, sandstone porosity-depth plot for the interval 5450-11625 ft representing the Agbada Formation in well 3 shows two characteristics. The intervals of 5450-9658 ft show an increase in porosity with porosity $\left(r^{2}=-0.899\right)(F i g .6 A)$ and porosity reduction with depth $\left(r^{2}=0.65\right)$ at the intervals of $9769-11625 \mathrm{ft}$ (Fig.6B) at the base of the well. Permeability values for this well are generally very low (less than 7 millidarcy; $\mathrm{md}$ ). Plots of sandstone porosity and water saturation versus depth show a slight decrease in porosity with increasing depth and water saturation at the base of the wells (Fig.7). 

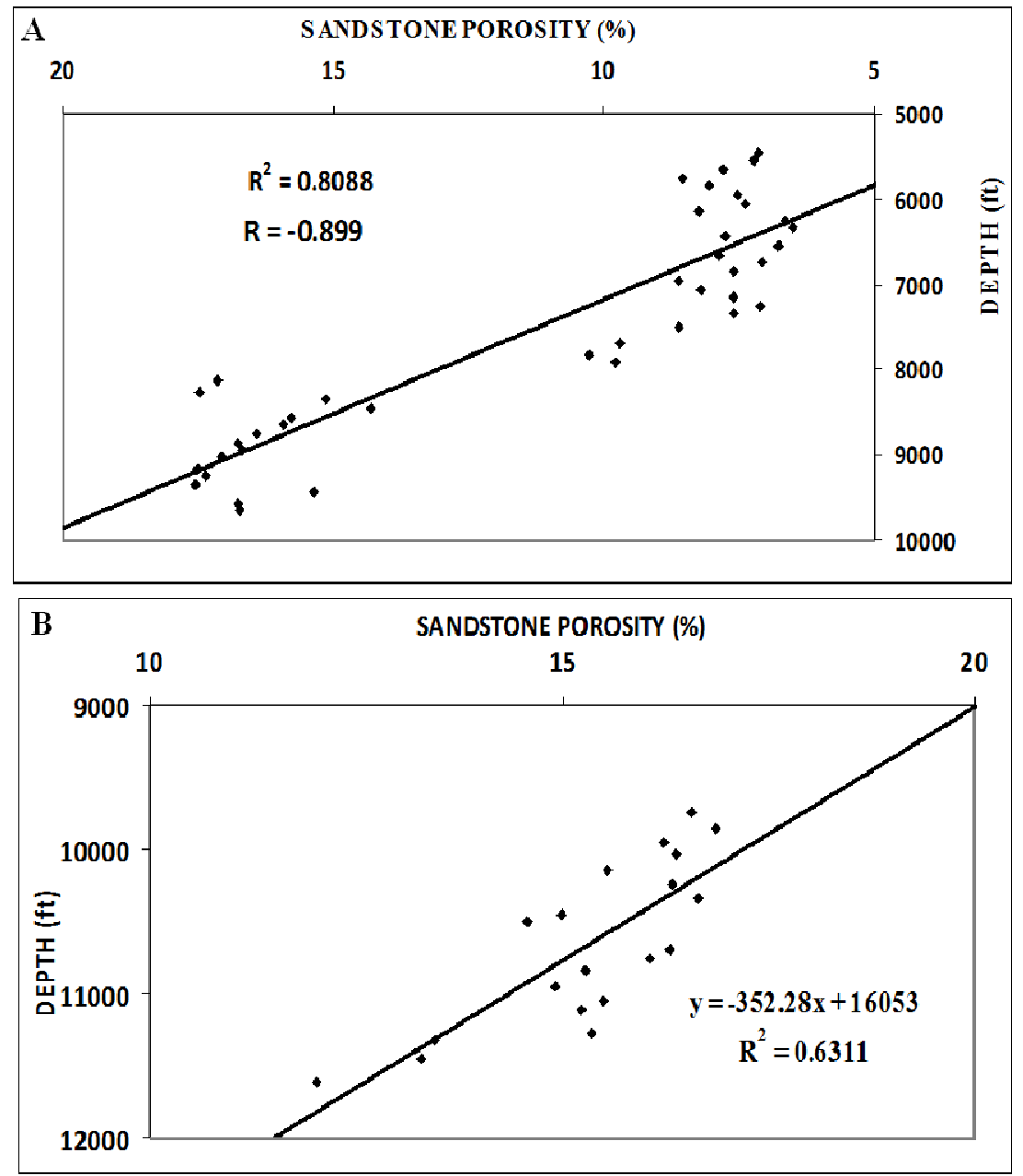

Fig.6: Sandstone Porosity-depth plot for (A) the 5450-9658 ft intervals (increase in porosity with depth) and 9746$11620 \mathrm{ft}$ intervals (decrease in porosity with depth) in well 3. 

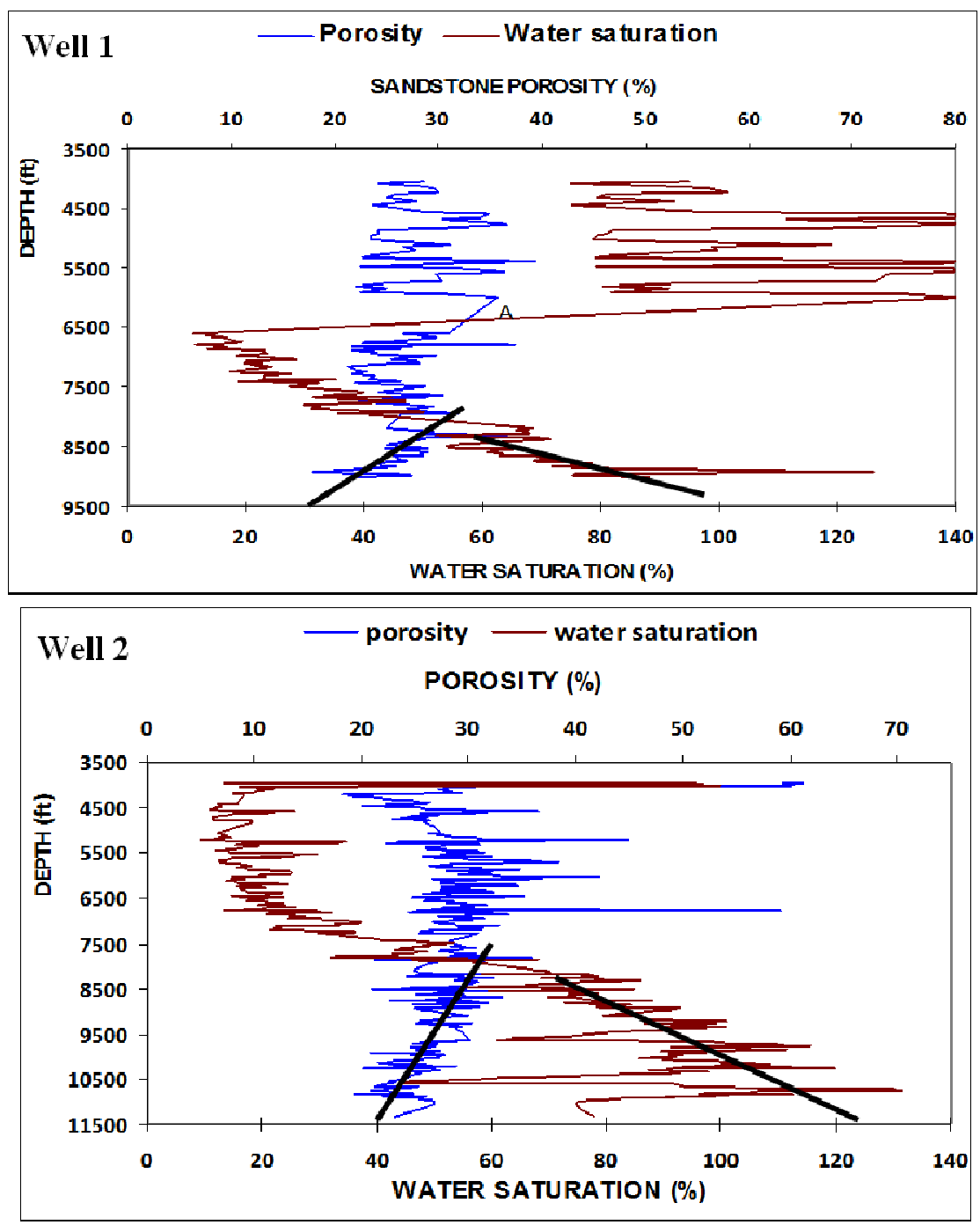

Fig.7: Plot showing the variation of porosity with water saturation and depth for wells 1 and 2.

- Indicates the decrease in porosity with increase in water saturation)

On the other hand, the shale porosity-depth plots for wells 1 and 2 show a linear trend of porosity reduction with depth (Fig. 8). This trend was observed even in shale adjacent to the sandstone intervals of insignificant porosity reduction. In well 3 , a reduction in shale porosity with depth $\left(r^{2}=0.49\right)$ was observed within the first $5000 \mathrm{ft}(2300-7218 \mathrm{ft})$. Porosity increased $(r=-0.596)$ with depth at the intervals of 7482-9769 ft (Fig. 9A) and decreased with depth $\left(r^{2}=0.65\right)$, at the base of the well (9769-11625 ft) (Fig.9B). 

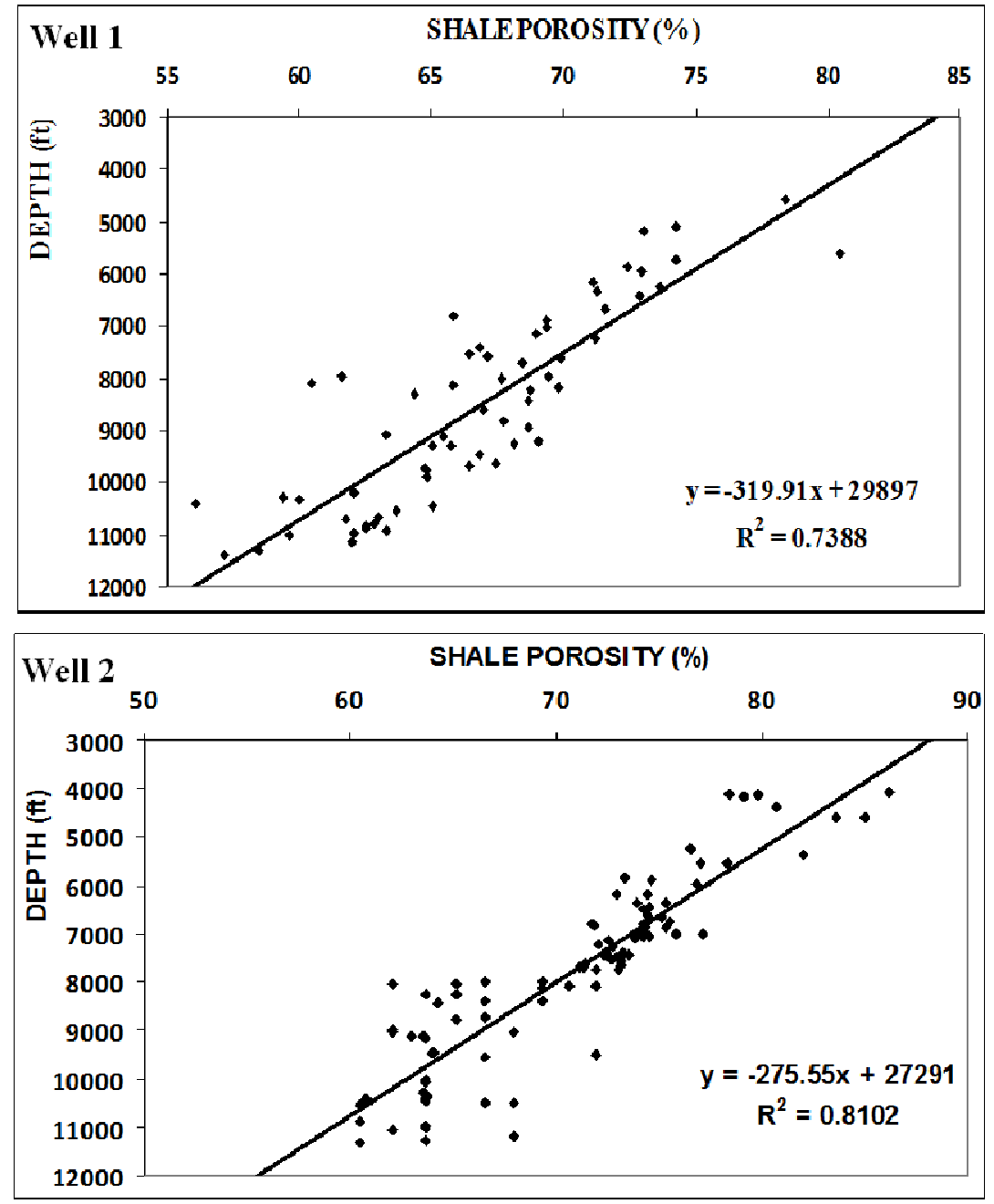

Fig.8: Shale Porosity-depth plots for well 1 and well 2; all show decreasing porosity with depth

The pore pressure evaluated for the intervals of $2300-7218 \mathrm{ft}\left(r^{2}=0.73\right)$ in well 3 (interval of porosity increase with depth) was found to be lower than that estimated from the actual porosity-depth curve (Fig 10). 

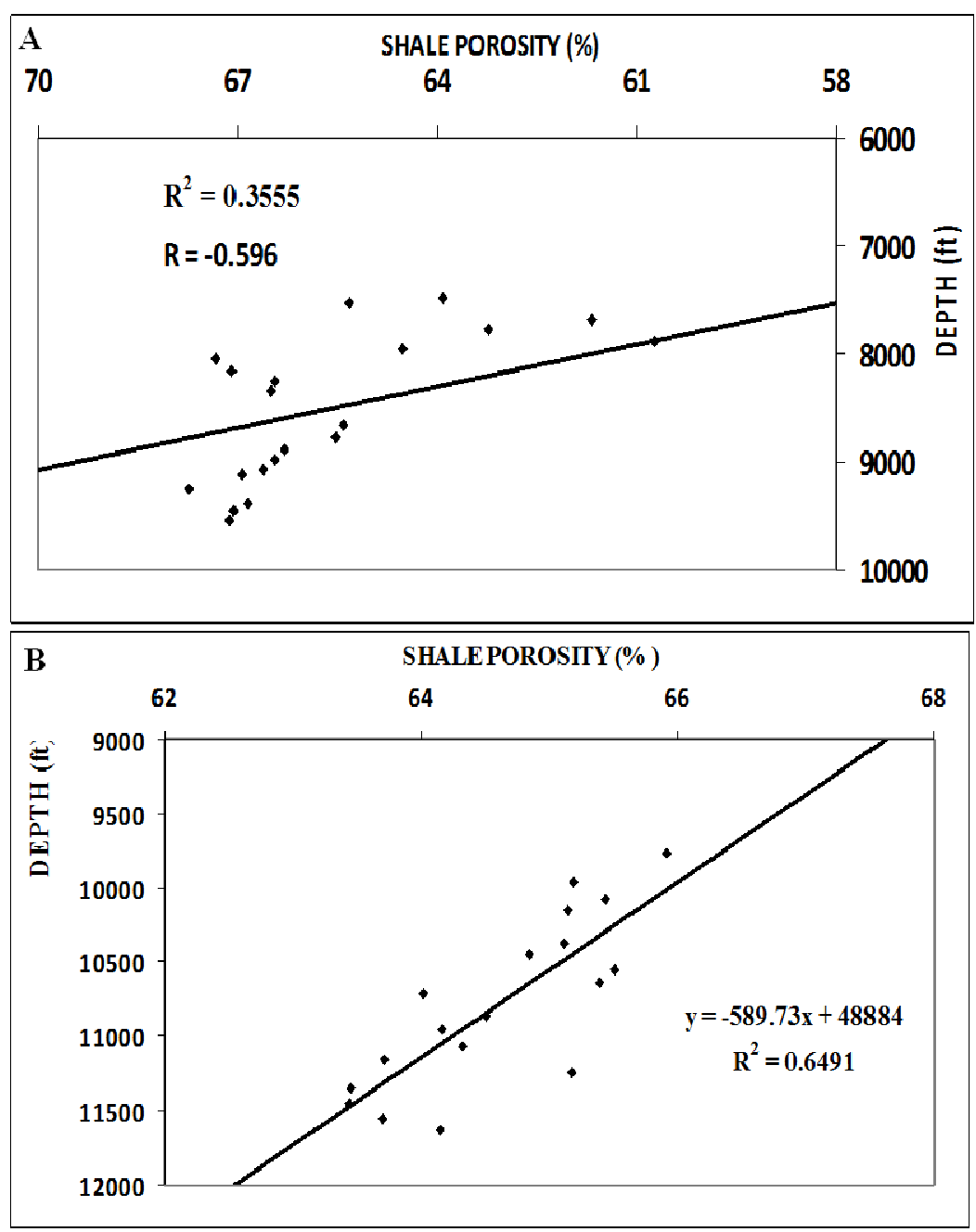

Fig.9: Shale Porosity-depth plot for (A) intervals of 7482-9769ft and intervals of 9769-11625ft in well 3 . Plot shows increase in porosity with depth in "A" and decrease in porosity with depth in "B". 


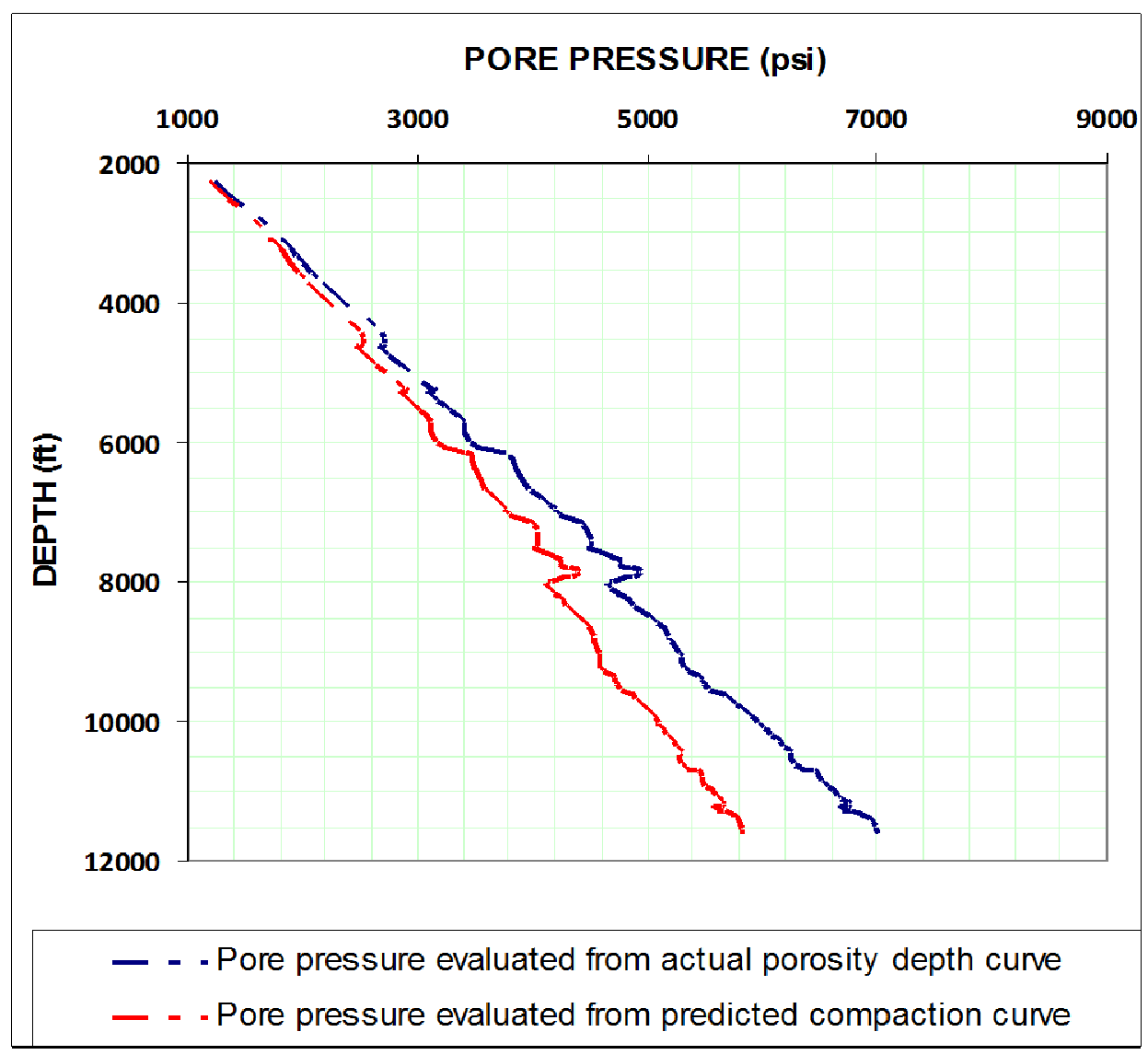

Figure 10: Plot showing the difference in pore pressure evaluated from the actual and predicted compaction curves for Well 3

\section{DISCUSSIONS}

Porosity reduction in shale is mainly controlled by mechanical compaction; this explains why the degree of compaction for the shales is higher (Table 2) than the sandstones (Table 1). The extreme compaction of shales is of great importance to petroleum geologists, because organic rich shales are potential source rocks. The compaction process aids in expelling hydrocarbons from mature source rocks into porous rocks to form petroleum pool in traps. 
Table 1: Compaction Data for Sandstone in the Agbada and Benin formations, Niger Delta

\begin{tabular}{|c|c|c|c|c|c|c|c|}
\hline & $\begin{array}{l}\text { Well } \\
\text { number }\end{array}$ & $\begin{array}{l}\text { Depth } \\
\text { interval (ft) }\end{array}$ & $\begin{array}{l}\text { Initial } \\
\text { porosity } \\
(\%)\end{array}$ & $\begin{array}{l}\text { Reference } \\
\text { depth (ft) }\end{array}$ & $\begin{array}{l}\text { Referenc } \\
\text { e porosity } \\
(\%)\end{array}$ & $\begin{array}{l}\text { \% } \\
\text { Compactio } \\
\text { n }\end{array}$ & $\begin{array}{l}\text { Compactio } \\
\text { n } \\
\text { Coefficient } \\
\left(\mathrm{m}^{-1}\right)\end{array}$ \\
\hline \multirow{3}{*}{$\sum_{\underset{m}{Z}}^{z} \sum_{u}$} & 1 & $0-5900$ & 72.33 & 5900 & 31 & 68.9 & $1.4 \times 10^{-04}$ \\
\hline & 2 & $0-5000$ & 70.84 & 5000 & 30 & 58.3 & $1.7 \times 10^{-04}$ \\
\hline & 3 & $0-5350$ & 36.1 & 5350 & 6 & 31.9 & $3.3 \times 10^{-04}$ \\
\hline \multirow{4}{*}{ 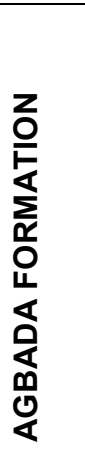 } & & & $\begin{array}{l}\text { Average } \\
\text { Porosity at } \\
\text { the top of } \\
\text { the } \\
\text { formation } \\
\text { (\%) }\end{array}$ & $\begin{array}{l}\text { total depth } \\
\text { (ft) }\end{array}$ & $\begin{array}{l}\text { Porosity at } \\
\text { total depth } \\
(\%)\end{array}$ & & \\
\hline & 1 & $6500-11388$ & 30.9 & 11388 & 7.52 & 25.29 & $1.2 \times 10^{-04}$ \\
\hline & 2 & $5760-11343$ & 30 & 11343 & 5.86 & 25.64 & $1.4 \times 10^{-04}$ \\
\hline & 3 & $9769-11625$ & 17.83 & 11625 & 12.56 & 6.03 & $3.02 \times 10^{-05}$ \\
\hline
\end{tabular}

Table 2: Compaction Data for shale, Niger Delta

\begin{tabular}{|l|l|l|l|l|l|l|l|l|}
\hline $\begin{array}{l}\text { Well } \\
\text { Number }\end{array}$ & $\begin{array}{l}\text { Total } \\
\text { depth } \\
\text { (ft) }\end{array}$ & $\begin{array}{l}\text { Porosity(\% } \\
\text { )at Total } \\
\text { depth }\end{array}$ & $\begin{array}{l}\text { Initial } \\
\text { Porosity } \\
(\%)\end{array}$ & $\begin{array}{l}\text { Reference } \\
\text { depth (ft) }\end{array}$ & $\begin{array}{l}\text { effective } \\
\text { stress at } \\
\text { reference } \\
\text { depth (psi) }\end{array}$ & $\begin{array}{l}\text { Reference } \\
\text { Porosity } \\
(\%)\end{array}$ & $\begin{array}{l}\text { Compressibilit } \\
\mathbf{y} \text { factor }\left(\mathbf{m}^{-1}\right)\end{array}$ & $\begin{array}{l}\text { \% } \\
\text { Compaction }\end{array}$ \\
\hline 1 & 11388 & 57.86 & 93.45 & 11388 & 4933.34 & 57.86 & $9.72 \times 10^{-05}$ & 84.46 \\
\hline 2 & 11343 & 57.89 & 99.04 & 11343 & 4912.09 & 57.89 & $1.09 \times 10^{-04}$ & 97.72 \\
\hline
\end{tabular}

The intervals of insignificant porosity reduction coincide with the hydrocarbon bearing zones, while porosity reduction is observed in the water bearing intervals below. This shows that primary porosity could have been preserved throughout the entrapment of hydrocarbons in the sandstones (O'Brien, 1986; BjØrkum et al, 1998). There is a widely held assumption that hydrocarbon emplacement physically "shuts down" diagenetic reactions (Wilson, 1990), by excluding water (wetting fluid) from reaction sites and restricting fluid mobility, this results in higher porosity and permeability in hydrocarbon bearing rocks than water bearing rocks. This explains the occurrence of the compaction curves in the water bearing zones.

Compaction plays a more significant role in sandstone porosity reduction of the Benin Formation (well 1: $68.9 \%$ and well 2: $58.3 \%$ ) than in the Agbada Formation (well 1: $25.29 \%$ and well 2: $25.64 \%$ ). Sandstone porosity values predicted at the bottom of well 1 and 2 (Table 1) are low; implying that the reservoirs at these depths may be uneconomical. However, it must be taken into consideration that porosity predictions in an oil zone may be much lower than observed, since hydrocarbons can preserve porosity.

The abrupt increase in porosity observed in well 3 could have resulted from overpressure. Undercompaction (compaction disequilibrium) is the most suitable overpressure mechanism that explains overpressures in Tertiary deltas like the Niger Delta, where rapid deposition and subsidence occur (Yassir and Addis, 2002). Undercompaction relies on the hypothesis that overpressured shales should have a higher porosity than normally pressured shales for a given depth (Hart et al., 1995) as observed in well 3. Low permeability can cause pore fluids to escape at rates insufficient to keep up with the rate of increase in vertical stress. The pore fluid tends to bear a large part of the 
overlying sediments weight, resulting in an increase in pore-fluid pressure (Hart et al., 1995; Osborne and Swarbrick, 1997; Bowers, 1993; Gordon and Flemings, 1998).

\section{CONCLUSIONS}

Some degree of compaction was observed at the top of all wells studied $\left(r^{2}=0.26,0.42\right.$ and 0.73 at 4500 $5900 \mathrm{ft}, 3940-5000 \mathrm{ft}$ and $2500-5350 \mathrm{ft}$ for wells 1,2 and 3 respectively). Intervals of insignificant porosity reduction with depth $\left(r^{2}=0.00003\right.$ and 0.008) observed at 6500-7950ft (well 1) and 5760-7911ft (well 2), coincide with the hydrocarbon bearing zones delineated (6480-7410ft and 6900-8500ft, for wells 1 and 2 respectively) and are interpreted to have resulted from the preservation of primary porosity throughout the entrapment of hydrocarbons in the sandstones.

An interval (7482-9769ft) of increase in porosity with depth $(r=-0.596)$, observed in well 3 is interpreted to have resulted from overpressure. Shale compaction data (compaction coefficient $=6.25 \times 10^{-05}, \varnothing_{0}=76.61, \varnothing=65.9$ ) evaluated from the top of the well 3 was used to predict a compaction curve at the over-pressured interval.

The compaction curve at the over-pressured interval shows that at the top of the wells (2000-6000ft), where the formation is mainly sands (Benin Formation), porosity reduction with depth is not influenced by hydrocarbon entrapment, permeability or fluid pressure, as observed in the hydrocarbon bearing sand/shale succession (Agbada Formation, 6000-12000ft). Even though hydrocarbon entrapment enhances reservoir quality by preserving porosity, reservoir quality gets poorer with depth below the hydrocarbon bearing zones due to compaction. Porosity values estimated at depths $11388 \mathrm{ft}$, (7.52\%; well 1$)$ and $11343 \mathrm{ft}$ (5.86\%; well 2$)$ show that reservoirs at such depths may be uneconomical. Statistically, it is difficult to isolate the effect of single factors (hydrocarbons, permeability and fluid pressure) on the porosity-depth gradient but such variations need to be considered when predicting reservoir quality, in order to avoid over or under estimation of undiscovered petroleum resources.

The knowledge of overpressure is necessary to ensure safe drilling of wells. Known porosity-depth trends and compaction data is useful for the undrilled portions of the depobelt, but this knowledge has to be applied at a local level or else predicted uncertainty will be too large to be useful.

\section{REFERENCES}

Asquith, G. and Krygowski, D., 2004. Basic Well Log Analysis. AAPG Methods in Exploration Series: $16,204 p$.

Athy, L. F., 1930. Density, porosity and compaction of sedimentary rocks. AAPG Bulletin: 14, 1-24.

BjØrkum, P. A., Oelkers, E. H., Nadeau, P. H., Walderhaug, O. and Murphy, W. M., 1998. Porosity prediction in quartzose sandstones as a function of time, temperature, depth, stylolite frequency, and hydrocarbon saturation. AAPG Bulletin: 82 (4) 637-648.

Bowers, G. L., 1993. Method for estimating pore fluid pressure. U.S patent, No. 5200929, 9p.

Doust, H., 1989. The Niger Delta: Hydrocarbon Potential of a Major Tertiary Delta Province Coastal Lowlands, Geology and Geotechnology. Proceedings of the KNGMG Symposium "Coastal Lowland Geology and Geotechnology". Dordrecht, Kluwe, 203-212.

Einsele, G., 1992. Sedimentary basins. Evolution, facies and sediment budget. Springer Verlag Berlin Heideberg: 628p.

Evamy, D. D., Haremboure, J., Kamerling, P., Knaap,

W. A., Molloy, F. A. and Rowlands, P. H., 1978. Hydrocarbon Habitat of Tertiary Niger Delta. AAPG Bulletin. 62, 1-39.

Flemings, P. B. and Lupa, J. A., 2004. Pressure prediction in the Bllwinkle Basin through petrophysics and flow modeling (Green Canyon 65, Gulf of Mexico). Marine and Petroleum Geology, 21, 1311-1322.

Gluyas, J. and Cade, C. A., 1997. Prediction of porosity in compacted sands with increment in depth. AAPG Memoir 69, 1-18.

Gordon, D. S. and Flemings, P. B., 1998. Generation of overpressure and compaction-driven fluid flow in a Plio-Pliestocene growth-fault basin, Eugene Island 330, offshore Louisiana. Blackwell Science Ltd. Basin Research: 10, 177-196.

Haney, M., Snieder, R. and Ampuero, J. P., 2007. Spectral element modeling of fault plane reflections arising from fluid pressure distributions. Geophysical Journal International, 170 (2), 933-951.

Hart, B. S., Flemings, P. B. and Deshpande, A., 1995. Porosity and pressure: Role of compaction disequilibrium in the development of geopressures in a Gulf Coast Pleistocene Basin. Geology: 23, 45-48.

Hubbert, M. K. and Rubey, N. W., 1959. Role of fluid pressure in mechanics of overthrust faulting. AAPG Bulletin: 70, 115-166.

Luo, X. and Vasseur, O., 1992. Contributions of compaction and aquathermal pressuring to geopressure and the influence of environmental conditions. AAPG Bulletin: 76 (10), 1550 1559. 
Merki, P. J., 1970. Structural geology of the CenozoicNiger Delta. Journal of Geology, 2 (3), 635-646.

Nagumo, S., 1965. Compaction of sedimentary rock- A consideration by the theory of Porous media. Bulletin of Earth quake research institute: 43, 339-348.

O’Brien, J. J., 1986. The preservation of primary porosity through hydrocarbon entrapment during burial. SPE Formation Evaluation: 1(3), 295-299.

Osborne, M. J., and Swarbrick, R. E., 1997. Mechanisms for generating overpressure in sedimentary basins: A reevaluation. AAPG Bulletin: 31(6), 1023-1041.

Reijers, T. J. A., 1995. Reservoir Geological Core Distribution using Standardized lithofacies and their Associations in the Tertiary Niger Delta. NAPE Bulletin: 10, 27-39.

Short, K. C. and Stauble, A. I., 1967. Outline of Geology of Niger Delta. AAPG Bulletin: 51, 761-779

Stacher, P., 1995. Present Understanding of the Niger Delta Habitat. In: Oti M. N. and Postma G. (eds). Geology of Deltas. A. A. Balkema Publishers, Rotterdam: 1st edition, 257 - 267.

Stump, B. B., Flemings, P. B., Finkbeiner, T and Zoback, M. D., 1998. Pressure difference between overpressured and bounding shales of the Eugene Island 330 field (offshore Louisiana, U.S.A) with implications for fluid flow induced by sediment loading. In: Mitchell, A and Grauls, D. (eds). Overpressures in petroleum exploration: workshop proceedings, Elf Exploration Production Memoir 22.

Swarbrick, R. E., 2002. Challenges of porosity-based pore pressure prediction. CSEG Recorder, 7477 .

Tuttle, M. L. W., Brownfield, M. E., and Charpentier, R. R., 1999. Tertiary Niger Delta (Akata-Agbada) Petroleum system, Niger Delta Province, Cameroon and Equatorial Guniea, Africa. U.S Geological Survey Open File Report 99-50 H, 113.

Weber, K. J., and Daukoru, E., 1975. Petroleum Geology of the Niger Delta. Proceedings of the $9^{\text {th }}$ World Petroleum Congress, Tokyo: 2 , 202-221.

Wilson, H. H., 1990. The case for early generation and accumulation of oil. Journal of Petroleum Geology, 13 (9), 127-156.

Yang, Y., Aplin, A. C. and Larter, S. R., 2002. Quantification, Permeability and Compaction of Mudstones: Some Applications to Basin Modelling and Pore Pressure Estimation. AAPG Annual Meeting. 7p.

Yassir, N. and Addis, M. A., 2002. Relationship between pore pressure and stress in different tectonic settings, in A. R. Huffman and G. L. Bowers eds., Pressure regimes in sedimentary basins and their prediction: AAPG Memoir 76, 76-78. 